\title{
Comparative study of Graphic aspects of textiles in Indian Gurakani and Iranian Safavid eras
}

\author{
Elahe MORAVEJ ${ }^{1}$ \\ M.Sc. student of visual communication of Alzahra University, Tehran
}

\begin{abstract}
The extensive support for the textile production industry and art from kings of 2 simultaneous Safavids and Gurkani Dynasties in Iran and India helped its promotion. In these periods, valuable textiles which played a significant role in expressing the individuals' social dignity were provided with valuable fibers, rare colors and particular designs. The main goal of this research is to comparatively analyze the Iranian textiles designs in Safavids and Indian ones in Gurkani dynasties during 9-11th centuries ( $\mathrm{AH})$ so that it can find the similarities and differences in term of designs and color of the textiles in these 2 countries and the level and reason for their effectiveness. This research focused on designed courtier textiles whose images and samples remained and are available. Investigation into the political-cultural relationship between these 2 dynasties, techniques, the materials and instruments used in textiles, itineraries and historical and research books and designs analysis on the basis of the available images and pictures were performed. The findings indicated that the level of effectiveness of technique and Iranian textile design were more than its vice versa state. The textiles colors were often similar, but the emphasis on some colors in Indian textiles seems particular. The effect of European on Indian designs is more than Iranian samples and the effect of religious and literature on Iranian artists and textile designs were more than those of Indian.
\end{abstract}

Keywords: Courtier Textiles, textile designs, Safavids, Gurkani

9-1 $1^{\text {th }}$ centuries (AH) are approximately the climax periods of 2 great Islamic dynasties called Safavids and Mongolian/Gurkani. These dynasties in this period of time often had friendly relationships and cultural exchanges and many textiles in these 2 dynasties were sold in other countries. In this research, the focus is on the textiles of royal factories and workhouses under the control of government. The reason for this is that the sample, picture and description and interpretations of these samples were more than market and domestic products, since they were of more importance and value and were better preserved. Furthermore, high humidity in Indian climate destroyed many of its domestic textiles and the market products were either simpler and without design (particularly in India) or they designs were simpler or reflected

${ }^{1}$ Email: elahemoravej@ymaill.com 
the simple designs or courtier designs on textiles consumed by people. The extensive relationships between Iran and India, textile trading as well as artists' immigration and as a consequence words and colors and textiles design were significantly effective and this process was a bilateral trend. The designs differences depended on the material, instruments, techniques as well as aesthetic vie and historical, mythological and religious effects. Colors also were used in different manners depending on pigments available and different views about them. Different colors were traded from Iran to India and vice versa. Iranian experts were famous in India and bilateral trading of the textile was promoting. Different types of cotton textiles as the most important Indian fibers were exported to Iran and the highlighted samples of silk and golden Iranian textiles were exported for officials and authorities etc. Iranian Cashmere scarfs and Kashmir products are also made of wool fiber which diversified ancient Bote-Jeqeh designs and made it globally famous which, of course; was due to the extensive Kashmir scarf trade to Europe by western companies.

The most important reason for comparative analysis of the designs is to better recognize each design in order to understand their historical origins and how these designs were preserved during these times, how they were modified or destroyed. This process is a good path to understand the ancient history and the art and industry importance. Since the issues investigated are required to be provided comparatively, as a result, first each textile design and color in Iran and India would be individually analyzed and categorized. Then, they are compared with each other so that one can find to which extent they were effective and affected by the other one. Clearly, the proposed questions include:

1. How were the Iranian (Safavids) and Indian (Gurkani) textile designs?

2. How were the Iranian (Safavids) and Indian (Gurkani) textile colors?

3. How Iranian and Indian textile did influence each other?

\section{Literature review}

So far, comparative analysis on Iranian and Indian textiles was not conducted, but it there are different researches on the characteristics and qualities of each one, separately. In contemporary age, the researches conducted in historical textiles focuses on issues more pervasively. Investigation into related occupations to this art in Safavids is one of them. Arthur E. Pop is one of pioneers of research on art of Safavids' age and among Iranian researched, one can mention Jalil Zia Pur and Dr. Beheshti were the first to investigate this issue. Also, most of valuable researchers were Iranian. This issue holds in India, too. The other point to note about Indian textiles is that, due to particular situation, climate, few of the historical textiles remained from India and the majority of contemporary researches investigated the current similarity and difference of different zones of India in order to preserve them and less viewed the issued in historical perspective. 
Diagram 1: Analytic model (Schematic diagram of theoretical framework) (reference: authors)

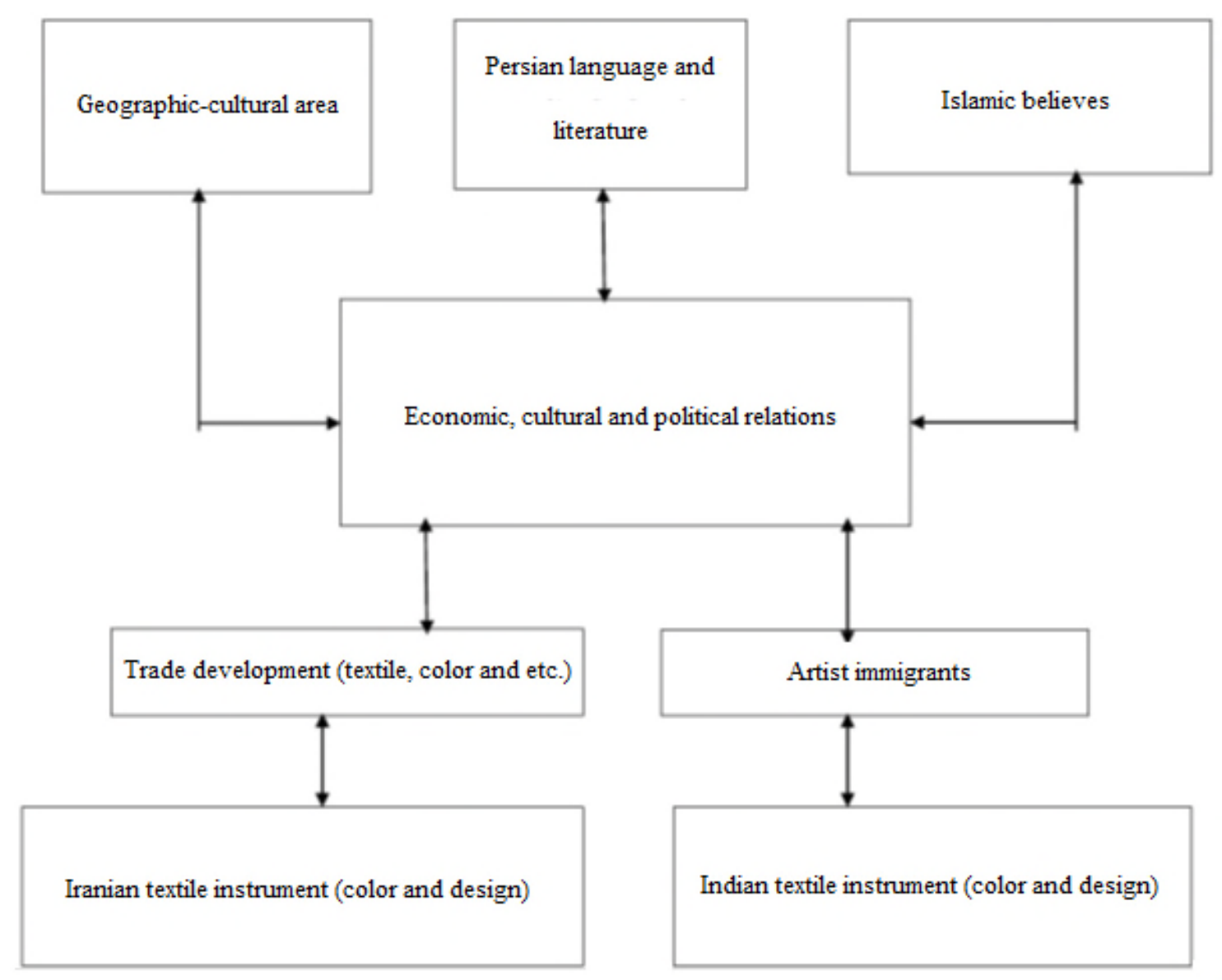

\section{History and Iranian textile production technique in Safavids}

Sheykh Safi Al-Din, son of Amin Al-Din Jabraieel (650-735 AH) attempted in such a way for guiding people to piety and virtue that majority of Minor Asia followed him. This dynasty was called Safavids in his memorial. King Abbas, son of King Mohammad Khodabande and his mother from Mazandaran Sadat Mar'ashi was fifth powerful king of this dynasty. Alsom King Tahmasb whose long ruling period led to revival of the economy (Rezaie, 1997: 310) was one of the other kings. From the period of Safavids government called King Firuz Zarin Kolah, the main Safavids dynasty's location was Ardebil. Many of the members of this dynasty were scientists abstemious and due to marrying the elders, they obtained the political power, too (figure 1). The last Safavids king, King Soltan Husain, lived in luxurious situation in spite of the political-economic issues. His stokes cotton and silk were for army cloths. The royal cloths stores, ride house and the content were burnt every seven years under the responsibility of Saheb Jam for recycling the golden fibers. Therefore, the Safavids sporadic treasures yield several gold bars y which the Zand government established an army consisting of 25000 soldiers (Baker, 1995: 113). 


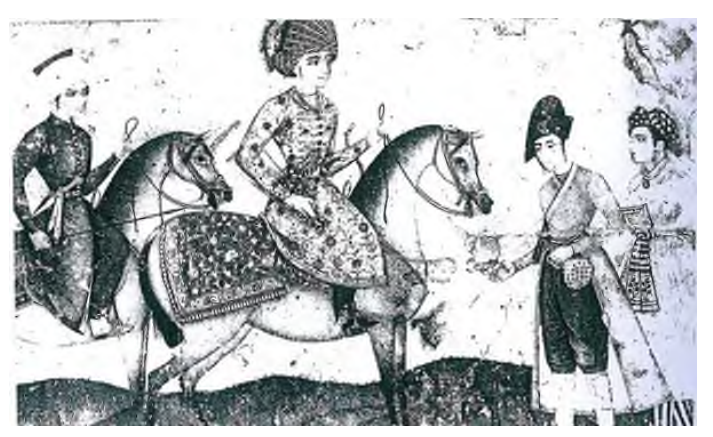

Figure 1: King Safavids Soleyman with a decorated cloth by designs of Abbasi flowers in accompanying with Mongolian and Europeans. The Mongolian man's belt is striped and is decorated with flowers in edges

The Safavids textiles include a large spectrum of products. The investigations can be divided into different sections such as texture, color, application and material. The textiles names provide us with different information. Some such as calico describe the way the designs are provided on the textiles (however, today, this is replaced with stamp or seal). The belt was used for waist and the term "Cashmere" remind us with abstract designs of the plants and Bote-Jeqe (curved-top Cedar designs). The inscription includes the written sentences suitable for religious places and points to the application of valuable fibers of gold and silver in textile. Approximately, all of the invented textile production techniques of those times were experienced in Iran. The progressive advances in producing textile led the industry of eastern creativity to an unexpected multi-layer complexity of the textile that 3 textiles were produced simultaneously but independent of the others and with a progressive exchange, they were designed based on the plan. Safavids Iranian sometimes provided more fine-arts using 2 systems simultaneously and in a level on textiles texture. The valure was not mentioned until 8-9 centuries $(\mathrm{AH})$ in documents also appeared in its most luxuries and glorious form during this time. Among simple textures, One and 2 sided Atlas, Jenai and Brokid textures in which in the textiles there were thicker textures in certain distances on the surface, was used frequently. Among other inventions of this age is a 2-layer or 2-dided textile which was produced from combining 2 simple textiles such that each had their individual design. For example, on side of the textile was red and the other side was white, woofs also were alternately white and red. One of the Qias-O-Din's products in produced in such a way using Leyli and Majnun design (figure 2). 


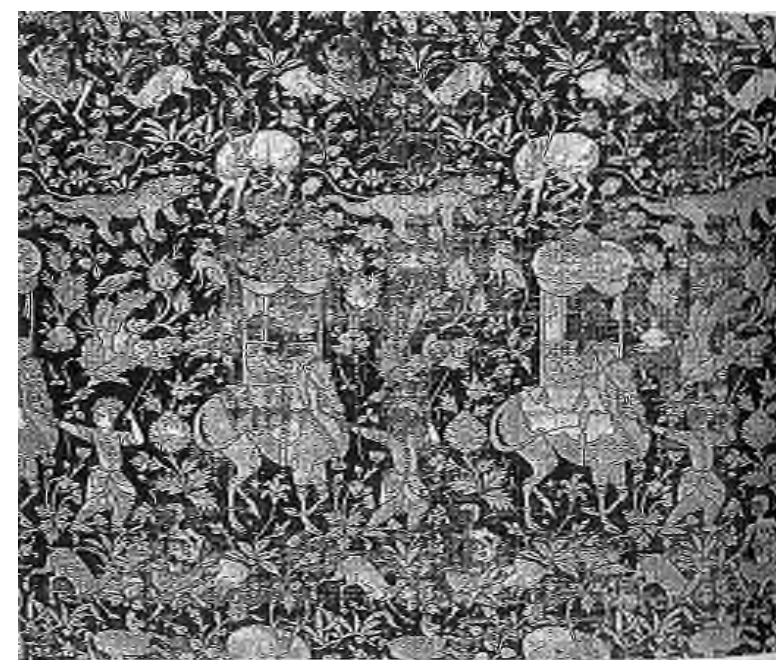

Figure 2: Lampas silk with Leyli and Majnun meeting design, Qias' work, Yazd of Isfahan (10-11 centuries $\mathrm{AH})$

Safavids textiles sometimes were produced of one type or 2 types of the fibers. The silk fiber and gold and silver fibers combination was the most famous sample. Iranian was interested in Cashmere scarfs highly. The elders of Iran made the cloths, curtains, uniform, duvet cover, horse blanket of cashmere. Most of these scarfs were produced in Kerman and Kermni weavers prepared the textures from goat hair which is shiny and soft like silk.

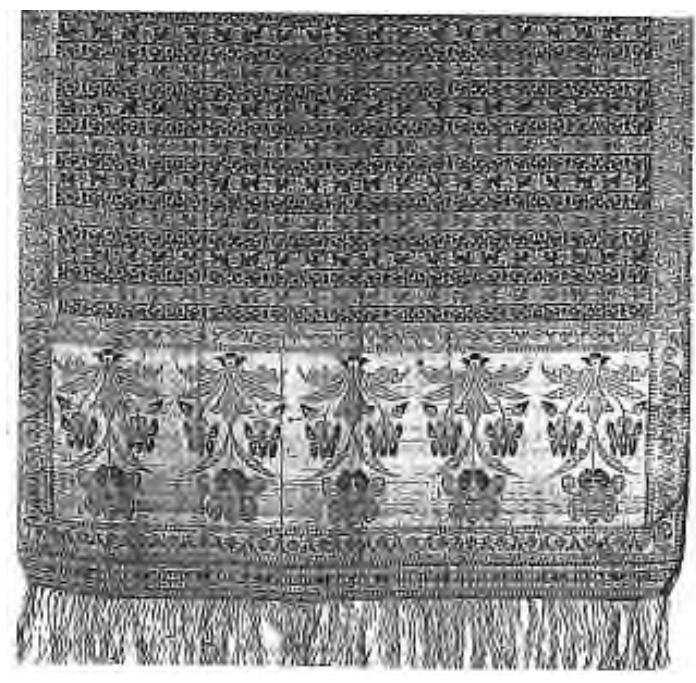

Figure 3: Iranian scarf design with individual flowers colored in green, yellow, light blue on an ivory background; narrow strips of the middle of scarf are worked with abstract designs

Marco Polo, who visited the Kerman in $13^{\text {th }}$ century, writes: the girls and women in this city are working broidery on these scarfs with silk and provide the birds, trees and flowers images on these textiles in a beautiful manner. These needle-worked textiles are so interesting and distinguishing that the rich persons exchanged them and used for curtain, pillow cover (Iranshahr, 1963: 1799). In Yazd also scarf producing was common and their texture and materials were not comparative to Kerman ones; since their texture was made of cotton (figure 3). The colors used in Cashmere was prepared of pomegranate, nut, oak, apple tree 
and poppy skin, Hanna leaves, Sumac, tea, berry or grapes and berry root, madder as well as mignonette, turmeric, saffron, indigo, baqm and Qantal (Qurchiani, 1991: 45). In this age, the wider textiles than seven-color ones were typically used for loose pants which were used by Zoroaster women (Anavian, 1975: 72). The other type was produced with colorful narrow strips and the same designs so that the pants would be prepared. This sample was prepared traditionally from different colors (DHamija, 1989: 75). The cashmere texture colors were typically light red, green, orange and black and the Bote-Jeqe, oval Bote, mastery Bote, cloak Bote, etc. are seen in these types (Yavari, 2000: 106).

\section{History and Indian textile production technique in Gurkani age}

Zahir-O-Din Mohammad, the prince whose background from his mother is Changiz Khan and from his father is Taymur, became the governor at the age of 12 in Fergana. His dream was to victory in possession of the Kandahar since 910 when he was in Kabul. The Kandahar is a city which is located in the way of Indian and Iranian trading roads and had a very important location due to its fertile lands, abundant water resources and stable castles. Baber, by winning in possessing the Kandahar at the time of the Safavids king Ismaiel with Ottomans in Chalderan war, obtained the key of possession of India. Ourang Zayb is the last of important king of Mongolian dynasty. After him, the dynasty was decomposed so that in $1266(\mathrm{H})$, the last remaining of the Gurkani dynasty was eliminated by Britain (figure 4).

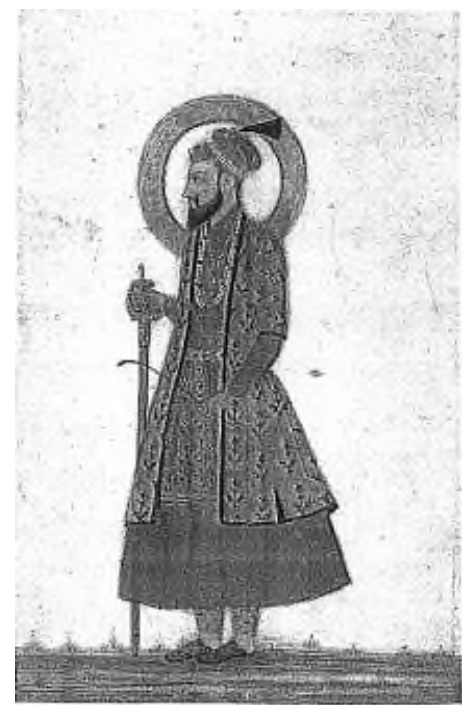

Figure 4: Gorgani Ourang Zayb (1658-1707), his cloth indicate the flower and his belt is designed with flowers, geometrical designs and art works.

The oldest Indian textiles obtained are the cotton and printed parts of Fustat in southern Cairo which was the center of middle age trading caravanserais. These parts date back to $8^{\text {th }}$ t0 15 centuries and obtained from different temples. These textiles are typical ones with moderate and suitable prices for typical classes and possibly were produced in Gujarat (Gillow and Barbard, 1996). After the Fustat examples, the oldest textiles with certain date are needlework silks of Putias ( $15^{\text {th }}$ century) which were obtained in china. The Gurkani textiles are produced of a type of fiber or in some cases of 2 or 3 types. The animal fibers used in Gurkani textiles were used in courtier and valuable textiles and only were the goal hair used 
in Kashmir woolen scarfs. The wool was not used in other Indian climates. The most important India fiber is cotton whose reputation is ancient. Different types of soft cottons attracted the advocates' attention to it due to its coolness. Among metal fibers only gold and silver and golden metals are significant in golden textiles production and making use of such metals during the periods gradually decreased. There are few examples of the Gurkani Atlas productions available; however, those examples are of glorious and daintiness. The scarf textiles often were prepared with oriented or oblique textures and the designing styles are also observable during their production on the brocade and valure types. There is no example of the 2-sided textiles with multiple layers obtained from Mongolian age. Typically, it can be stated that the diversity of textiles was more acceptable and favorable with help of painting and printing than making use of texture diversity in textiles. Of course, it is important to note that needlework was one of the most important arts in making the textiles diverse, particularly in Kashmir scarf. The brocade valure also was prepared in workhouses in India. The most famous Indian woolen product was the Kashmir scarf in Mongolian age. The Kashmir local tradition in designed scarfs production was established by foreign manufacturers at the time of Roshangar's kingdom, i.e. Zayn-Ol-Abbedin (1470).

\section{Comparative analysis of the Safavids and Gurkani textiles}

The designs of the Safavids textiles are observable in carpets, miniature and tiling. Particularly, the human figures in textile designs are mostly similar to the miniatures of this age. It is interesting that the human designs in Indian textiles are only seen in the curtains, but not in cloths. The continuity of the designs in these textiles is in such a way the viewer dynamically observes them. Each element is a complete image on its own and even the women and men images are different in a gender-like manner. Not merely the gender. The repetition in silk and valure cute designs are planned for reduction of vertical or horizontal emphasis. Sometimes, the miniatures are inversed in repetitive rows and in some cases, throughout the surface of the textile are covered by the design repetition in a length of more than 2 meters. Lack of rhythm and motion in how miniatures repetitions are organized is also important such as sitting figures or horse rider around the tree. It is interesting to know that the comparative analysis of and organizing the Indian and Iranian similar examples together is possible in order to understand the difference and similarity of designs for only some types. Among the inscription textiles samples there is no similar type in Indian Mongolian products and also the use of supplications and talismans was not common in army cloths which was conventional in Iranian and Ottomans one. The images on the textiles used for cloth in Indian Gurkani age are only nature designs and their designs are completely naturalistic or like Kashmir scarfs they are abstract types and of course, the plants is also used more than the animals. While, in Safavids age, the human and animal designs are frequently observed in cloths and the abstract nature was of the background importance. The other point to note is that the Mongolian valure didn't yield any picture for investigation and also the Kashmir scarfs examples of this age are similar to Iranian one in flowers designed on 2 edges of the scarf, but not similar to conventional Bote-Jeqe and rubiks and the application of Bote-Jeqe design and its different types on Kashmir scarfs is the invention of $11^{\text {th }}$ century (AH). An example of unique design in Safavids age is obtained from museum textiles in Russia which 
can belong to $17^{\text {th }}$ century and there are 5 stairs in an oblique direction along a small window or door and a full of flower pot covers the surrounding and below the window. In this design, the gold and silver are used. Blue, black, golden and silver colors are manifesting on a somehow red background (figure 5).

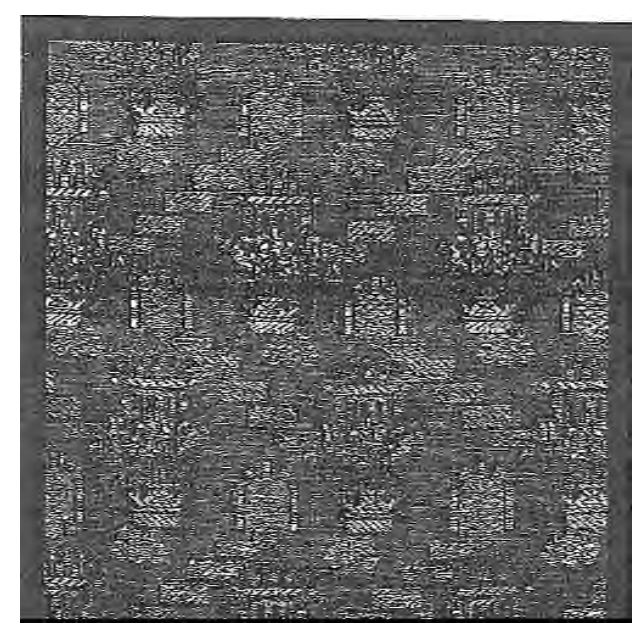

Figure 5: The Brocade silk textile $\left(11^{\text {th }}\right.$ century $)$ decorated by designs which have not been seen yet, Iran.

The comparative analysis in several pairs of the Gurkani and Safavids similar textiles is conducted in which their design differences are simply detectable. Both valuable overcoats remained from Safavids age are the valure examples with a buff background and designs of drinking adults repeated with a bush of flowers. The other which is preserved in Russian museum depicts the dragons' battle and it of valure (figure 6).

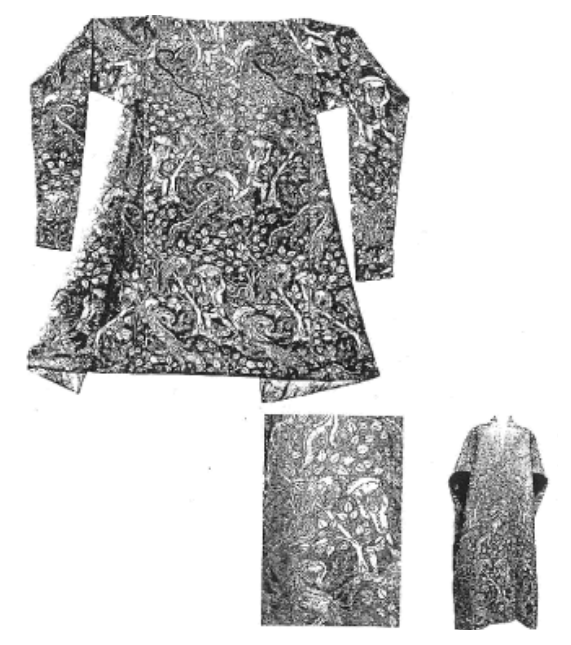

Figure 6: Silk robe of brocade valure or Gezelbash's cloth decorated with dragon design, Iran $\left(10^{\text {th }}\right.$ century $\left.\mathrm{AH}\right)$

The similar Gurkani overcoat belonged to Jahangir on which the designs are worked with fine sutures by Gujarat artists by silk needlework. The light and equivalent colors manifest the Iranian effects, but the nature, plants and animals are of realistic elements which is specific to 
Indian types (figure 7). In figure 7, there is no human picture whose main design was not found in 2 abovementioned types. There is a margin of needlework flowers on its edges which is of no place among Iranian cloths production styles since the design in Safavids age textiles are weaved not needlework products. The belt used among Iranian is decorated on both edges by bush of beautiful flowers and it is imitated by Indian, too (figure 8).

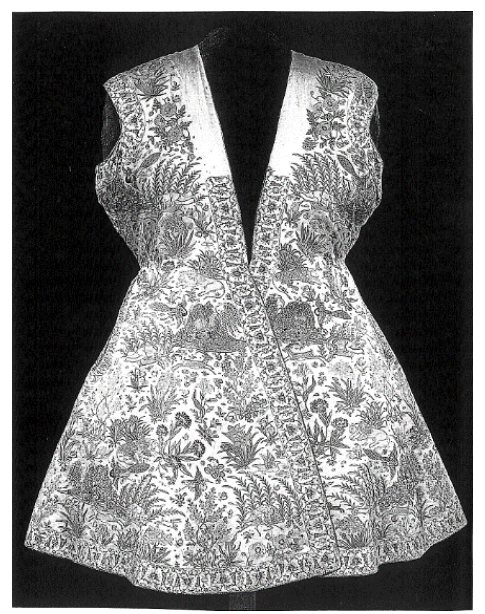

Figure 7: Hunt overcoat, needlework atlas with silk and chain fine sutures, India $\left(10^{\text {th }}\right.$ century $\left.\mathrm{AH}\right)$

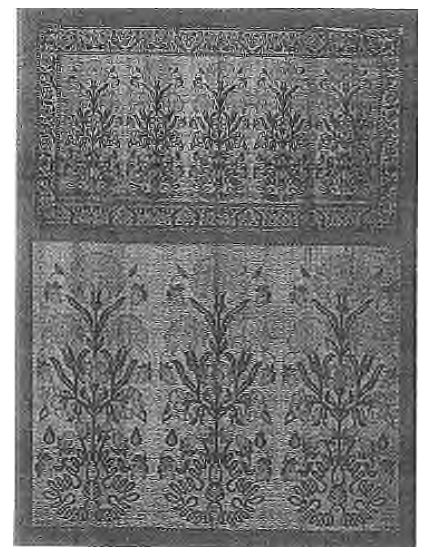

Figure 8: Iranian silk belt edges design decorated by individual bushes of clove $\left(11^{\text {th }}\right.$ century)

It is interesting that the height of these flower bushes increased gradually in India. The Kashmir scarfs were not used as belts among Indian and developed using individual plants abstract designs and later, particularly, by Bote-Jeqe decorative forms. The complex design of Bote-Jeqe also became longer and wider. Among other Iranian designs which are not found in India are the contrasting designs which in major are seen in 2 sides of the cedar tree. These designs are sometimes horse riders, walking figures or a pair of rams or peacocks. This ancient Iranian design in which the cedar tree presence is interpreted as the life tree was prepared with green, blue and yellow colors on a crimson background and indicated the producers' information about the color contrast (figure9). 


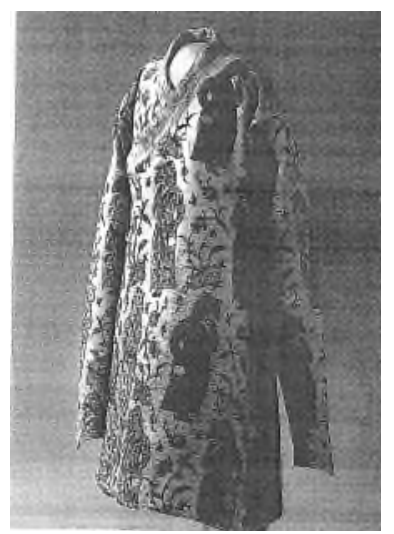

Figure 9: Silk valure cloak, Iran (11 $1^{\text {th }}$ century AH). The Russian Czar in 1644 presented this cloth as an award to Swedish Queen. Mongolian Jahangir age (16-5-1627), Gujarat.

The alter design which was used in Iran as the praying mat or wall-mounted curtains or in Imams' shrines and often were worked with valure techniques, were of wide applications in India. In India, it was used for the curtain, wall-mounted curtain or authorities' tent and it was not particular to the religious places. The main theme of this design was covered by a bush of flower in form of needlework or calico forms in which due to the unoccupied fields were more manifesting. While, in Iranian examples there is approximately no unoccupied areas observed and there are many occupying and continuing designs. In Indian samples there is no inscription seen. The diversity and thickness of the marginal flowers design is also less than Iranian types and as a result, they are more sedative (figure 10).

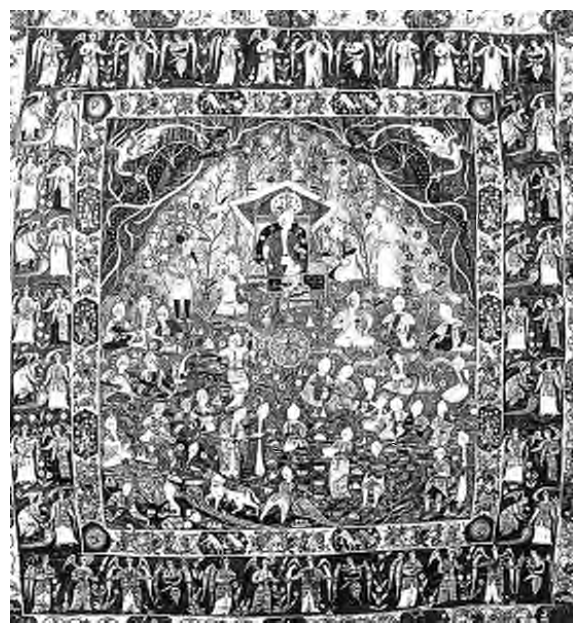

Figure 10: Esterhazy applique, silk and leather on a cotton textile, Tabriz $\left(10^{\text {th }}\right.$ century AH)

A single embroidery cotton textile fragment with silk and leather parts which was woven in $16^{\text {th }}$ century in Tabriz is called in the name of the Esterhazy's dynasty to which this fragment belonged. Below, an altar design of the banquet scene in an open space at the presence of the young king, possibly Tahmasb, is seen. The dragon vs. simurgh battle is above the altar and the margins are also decorated with winged angels, the Sun, the deer and lion pictures, art works and sitting figures under the tree and etc. various Iranian original symbols as well as the king's presence made it more manifesting. In similar geometrical samples, there is a 
painted and cotton printed part of Golconda design obtained which belonged to 1650 and is implemented under the clear influence of Iranian banquet designs and there are 3 knotted bergamot designs among the Mumal which divides it into 2 separate spaces and is the Iranian common and conventional designs too which is not seen in Indian examples. The margins are decorated with twisted flowers and 2 birds and a rabbit in a corner. Generally, the plan is asymmetric and background designs are not repetitive. In other similar example which is from Golconda and Jaipur, there are hunters manifested and in other picture the grandees are indicated in a palace in different states along with some Europeans. The narrative designs, contrary to the geometrical ones worked on floor covering, counterpane or wall-mounted curtains, were also used for cloths in Iran. The scene of Georgia war prisoners at the time of King Tahmasb are implemented on a crimson background on several types of the textiles in different forms (figure 11).

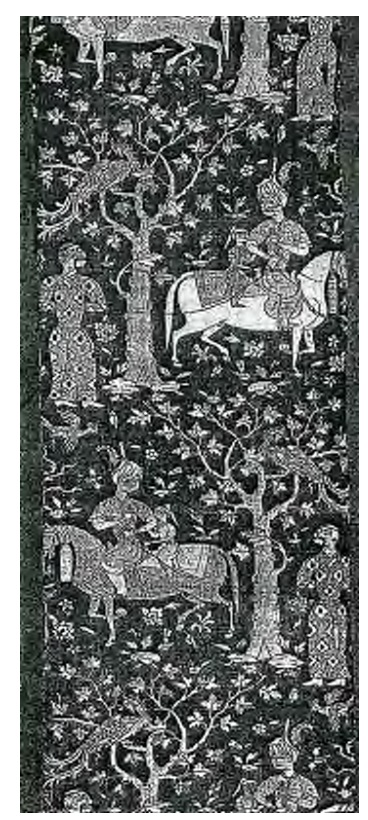

Figure 11: The silk Woven textile from King Tahmasb indicating the prisoners transfer path, Iran, Safavids age $\left(11^{\text {th }}\right.$ century $\left.\mathrm{AH}\right)$.

Few of the Iranian calico works also remained from $11^{\text {th }}$ century AH which are printed based on template (figure 12).

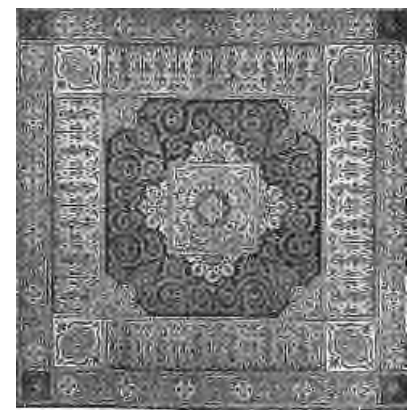

Figure 12: Calico work with a design similar to carpet on a Jenaqi silk textile, Yazd, $11^{\text {th }}$ century $\mathrm{AH}$ 
These calico textiles have similar designs to today designs; i.e. central bergamot, possibly with 4 Lackas and margins. The design of cedar which was specifically used in Iran is seen in the calicos of those ages, but these designs were not applicable in India. The Indian calicos are decorated by twisted flowers and it seems that less color is used in order to prepare them. An Iranian calico curtain from Ackerman-Pop's collection also demonstrates a design of flower pot along with altar which is formed from the pot fish design and there are 6 birds depicted on both sides of the pot. 2 lions are seen below the pot and next to the cedar designs. The background is also covered with small flowers (figure 13).

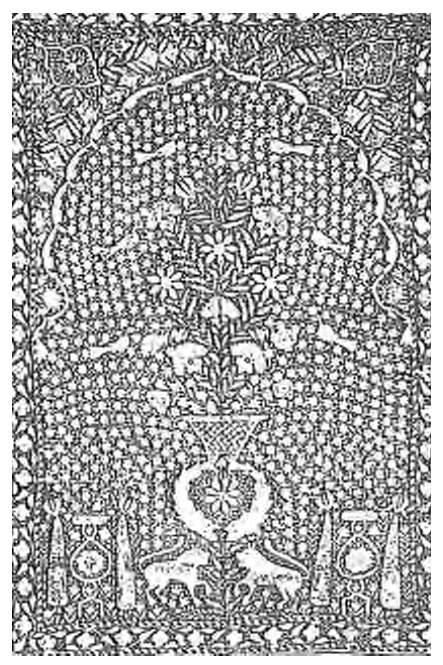

Figure 13: Iranian calico curtain, decorated by altar design with fish, $11^{\text {th }}$ century

The printed cotton designs in India consisted of the wide and twisting plants and flowers and the samples influenced by Iranian art are also minor and specific to the Golconda and Deccan printed cotton. This issue was due to the fact that the Shia rulers were in extensive relationship with Safavids' kings.

\section{Conclusion}

In answering the stated hypotheses and questions in this article, the colors and designs of textiles were investigated and the effects of the both lands' arts on each other were also studied. But, it may not be possible to answer this question that which country was more effective on the other. The Iranian and Kashmir Cashmere scarfs need more debates. Approximately, it is proved that the Iranian scarf weaving technique was transferred to Kashmir and Bote-Jeqe is originally an Iranian design, but it is interesting that Iranian BoteJeqe changed to a longer and wider and more applicable form and it was worked with needlework, but not with weaving. Ekat also is of long history in India and it is produced in mass production level, but at Safavids age Daraie Bafi (Weaving Daraie) was unknown and today it is forgotten completely. From differences between Iranian and Indian textiles and particularly their courtier types, one can mention that in Iranian textiles the order and asymmetry were mostly important. The bergamot's central role, occupied backgrounds, abstract nature, inscription, geometrical networks, historical and literal narrations, flowers and birds symbolic presence along with each other, presence of many human figures in these 
textiles' designs in nature and etc. are in a relative position to Indian long and narrow and highly naturalistic designs in which the textile background is mostly seen due to the lack of fully occupying designs, their narrowness and light colors such as white. In Iranian textile, often due to excessive occupying designs, the background is not attractive for the viewer. The common and shared point between both countries is that they have many similar designs and they are implements in such a way that none of them is superior to other and the viewer dynamically looks at them. Nature is the major design in Indian and human and nature and abstraction composed the designs of Iranian types. The Islamic art principles due to political situation and the government position, as earlier stated, was of more depth and place among Safavids Iranian and it is seen in different types of arts; where as in India due to lack long history of Islam and Gurkani kings such as King Akbar has a simple view on the religion and they were not interested in extending the Islam among diverse people, this element is not seen and the available cases often are influenced by Iranian types which are associated with Indian characteristics. Therefore, artist immigrants' color and textile import and exports and shared language and religion and the closed relationship between rulers are the most important effects of these lands' arts on each other which are becoming colorless during the periods of time due to climate, people demands and trading and changed or moderated some of the, in such a way that the valure weaving ended soon, Bote-Jeqe changed to Payzeli and the brocade also gradually became marginal

\section{References}

1. Ajand, Y. (2001), Iranian Safavids' history, Terhan, Jami

2. Iranshahr, (1963), Tehran, UNESCO University publication

3. Parham S. (1985), Fars rural and Nomadic hand works, Tehran, Amir Kabir

4. Pop, A. (2001), tradition and culture, Tehran, ministry of Islamic culture and guidance

5. Tarikh Bakhs, A (2008), Safavids' history, Shiraz, Navid

6. Fred, A W, (1995), Iranian arts, Tehran, Farza

7. Nematollahi S (1994), Textile weaving designing method, Tehran, Sorush

8. Wolf, H E (1993), Iranian old hand works, Tehran, Islamic revolution

9. Navaie A H. (1998), Iranian political and economic relations in Safavids age, Terhan, SAMT

10. Yavari H. (2000), Iranian traditional textile, Tehran, hand work organization

11. Sabet Irani, F (1965), Iranian Brocade, M.A. thesis, Beautiful Art University

12. Haiqi, G (2536), investigation into Iranian brocade textiles, M.A thesis, Beautiful Art University

13. Qurchiani, M (1991), a new glance at Iranian textiles, M.A thesis, Beautiful Art University

14. Mottaqi, M. (2003), Indian garment, M.A thesis, Shariati University

15. Anquetil, Jacques. (1995). Silk. Paris and New York: Flammariow.

16. Baker, Patricia. L. (1995).Islamic textiles. London: British Museum.

17. Cooper, Ilay and Gillow John. (1996).Artstandcrafts of London: Thames and Hudson.

18. Harris, Jennifer. (1993).5000yearsof textiles, london: British Musem.

19. Pop, Arthur upham. (Eds). (1971).Asurvey of persian Art.tokyo:meiji-shobo. 
Bulletin de la Société Royale des Sciences de Liège, Vol 85, 2016, p. 793 - 806

20. Von folsach, Kjeild. (2001).Art from the word of Islam in the David collection. Copenhagen: f. Hendri Knsens EFTF. 